\title{
Quality Management Profile of Tegar Kelana, a Private Vocational School in West Lombok: A Basis for the Development of Internal Quality
}

\author{
Dadi Setiadi* \\ Program Studi Magister Administrasi Pendidikan \\ Universitas Mataram \\ NTB, Indonesia \\ setiadi_dadi@unram.ac.id \\ Wildan Wildan \\ Program Studi Magister Administrasi Pendidikan \\ Universitas Mataram \\ NTB, Indonesia
}

\author{
Nyoman Sridana \\ Program Studi Magister Administrasi Pendidikan \\ Universitas Mataram \\ NTB, Indonesia
}

Fahruddin Fahruddin

Program Studi Magister Administrasi Pendidikan

Universitas Mataram

NTB, Indonesia

\begin{abstract}
Quality management of secondary education units is a quality assurance system implemented by all components in the education unit. Quality management in private high schools needs to be studied and resolved so that the quality of the process and learning outcomes of students can be on par with other schools. The purpose of this study was to determine the quality management system, and the obstacles encountered. Research subjects are teachers, principals and education personnel. The research approach used is a qualitative approach. Data collection techniques are carried out through document analysis, questionnaires and interviews with data sources such as teachers, school principals and education staff. Data were analyzed descriptively qualitatively with stages of data collection, preparation of data analysis, reading all, coding data, coding text for descriptions and themes used in research. The results showed that the teaching and educational staff as a whole did not understand the quality management of secondary education units. In addition, quality programs have not been well-organized in order to meet the standards of quality management, implementation and evaluation of quality management. Constraints faced in private Islamic high schools, all school members do not have a good understanding of planning, implementing, organizing and controlling related to quality. So that school programs do not lead to a gradual improvement in quality to achieve national education standards. Both schools need to be given understanding and guidance related to school quality improvement management in accordance with the vision and mission of the school and national education standards. As a first step, private high schools need to form appropriate quality planning in order to improve the quality of the administration and learning process.
\end{abstract}

Keywords - Quality Management, Internal Quality Development, Vocational School

\section{INTRODUCTION}

Quality management is a quality assurance system implemented by certain education units and involves all components in the education unit. Nationally, the quality of secondary education in Indonesia has not been as expected. National education quality mapping results show that only about $16 \%$ of education units meet the national education standard (SNP) (Directorate General of Primary and Secondary Education 2016). Most of the other education units do not meet the SNP, in fact there are a number of education units that still do not meet the minimum service standard (SPM).

The quality standard of education set by the government is different from the standard implemented by the education unit. The standards used by most schools are far below the standards set by the government. As a result, the quality of graduates produced by education units does not meet the standards set by the government.

There are still many education management teams who do not understand well the meaning of education quality standards. In addition, most education units do not yet have the ability to be able to guarantee that all processes carried out meet quality standards. The education unit must implement the quality assurance of education in a good and independent and sustainable manner. According to the Government of the Republic of Indonesia [1] in the form of Law Number 20 Year 2003 that the National Education System is an integrated whole component of education to achieve national education goals. In addition, each education unit is required to carry out education quality assurance that aims to meet or exceed the SNP.

The internal quality assurance system of secondary education, is an integrated element consisting of policies and processes related to the implementation of education quality assurance carried out by each secondary education unit to ensure the realization of quality education that meets or exceeds SNP. Efforts to improve and guarantee the quality of education are the responsibility of the education unit. To improve the overall quality of schools, especially private high schools in Mataram, a special approach is needed so that all school components together can have a quality culture.

To be able to carry out education quality assurance, education units need to establish a quality management 
system. Based on preliminary studies in West Lombok private high schools that are used as a sample shows that in these schools do not have a good quality assurance system in accordance with the standards and regulations that apply even if seen from the accreditation value reaches the highest standard. This will have an impact on the quality of graduates who cannot meet national standards while a number of other schools, both public and private, can already have good quality.

Thus a study is needed related to internal quality management in the school so that it can gradually lead to the achievement of national standards. even surpass it. Based on the description above, it is necessary to conduct research on internal quality management in private high schools in West Lombok as a basis for the preparation of quality implementation, control and evaluation programs in the education unit.

\section{METHODS}

The research approach used in this study is a qualitative approach where the researcher knows the participant's condition, asks broad questions, general questions, and data collection consists of a broad text of participants, explains and suggests the text for the theme and conducts inquiry, is subjective [2]. In addition, researchers as key instruments, triangulation of data collection techniques are carried out, data analysis is inductive, and the results of research emphasize more on meaning than generalization [3], [4].

The study was conducted from the end of May 2018 until the end of September 2018. The research sample was Muhammadiyah High School, NW High School (Nahdatul Wathan) Mataram with a focus on the problem of implementing an internal quality assurance system. Data sources are educators and education staff. Data collection techniques are done through document analysis, interviews, and questionnaires. The research instrument is used in the form of interview guidelines, questionnaires, document analysis guidelines. Data were analyzed and interpreted qualitatively by stages: Data collection, preparation of data analysis, reading all data, encoding data, encoding text for description used in research reports and descriptive analysis of data.

\section{RESULTS AND DISCUSSION}

The quality assurance system management in the sample schools was first conveyed on the understanding of the teaching and educational staff directly involved in quality management. The results show that the principal's understanding of the internal quality assurance system shows a score at a less level, whereas other education personnel with an understanding score are higher than the principal but still at a less level. Similarly, the understanding of teaching staff towards internal management is still lacking. In addition, educators and education staff do not understand well about the concepts and principles, goals and scope of the management of the education unit, it is important for the implementer of internal quality management, because if they lack understanding of the quality management, the management of the education unit will not be able to implement it optimally in accordance with the aim of school internal quality management. The solution, as suggested by [5], recommends that principals strengthen alternative quality management such as teacher appraisal, use of internal quality assurance officers by capacity building on requisite knowledge and skills.

Quality management is related to 8 national standards of education and with teacher assignments, it will be related primarily to graduate competency standards, content standards, process standards, evaluation standards and educator standards themselves. Next, the level of understanding of educators towards the competency standard of graduates scores 2, the Standard Content score 3 , the Process Standards score 2.0, and the Evaluation standard score 3 . In addition, those related to the standards of educators achieve a score of 3 . The understanding has only reached a sufficient level but for the standard of teaching staff is approaching well. However, to be able to carry out planning and evaluation in accordance with the standards, the level of understanding of educators must be above good. In addition, teachers accepted for teaching should be based on knowledge of curriculum content, professional qualifications determined by the government [6].

In conjunction with the implementation of quality management in schools that become research sites include a quality assurance cycle consisting of 5 stages, First, the mapping of the quality of education carried out by education units based on the National Education Standards. The education staff and school educators do not yet understand in detail about the stages of education quality planning starting from the preparation of instruments and data collection and analysis of mapping results that will be related to making plans for the next phase of the SPMI cycle. Activities at this stage include internal evaluations and can be carried out with the Plan, Do, Check and Act stages [7].

Second, making plans or quality programs as outlined in the School Work Plan, the school does not know how to make plans in accordance with the principles of quality management related to national education standards. The making of school programs related to quality management must be prepared based on the school self-portrait of the quality conditions when self-evaluation is carried out, then compile a number of work programs which are overall oriented towards improving the quality of school administration and learning processes.

Third, the implementation of quality fulfillment both in the management of the education unit and the learning process, at this stage also the management of the education unit has not fully understood this stage of the education unit's internal quality assurance cycle, it is related to the level of understanding of the previous stage, therefore it is necessary to study in depth related to the implementation of quality programs for quality fulfillment in the management of education units and the learning process at large. This requires the togetherness of all school members to jointly carry out school programs related to the fulfillment of the quality of education according to standards.

Fourth, monitoring and evaluation of the quality program implementation process that has been carried out, at this stage the school still needs good knowledge related to the role and function of monitoring and evaluation for each quality fulfillment program, so that it will be useful for 
the next process of preparing new standards and strategies for achieving quality planned.

Finally, setting new standards and developing quality improvement strategies based on monitoring and evaluation results. The management of the education unit does not yet have good knowledge and understanding of the preparation of new quality standards including their achievement strategies. The school still has to learn and prepare for the final stages of the internal quality assurance cycle. In programming the program must be totally holistic process concerned with ensuring integrity of outcomes [8].

The school as a whole does not yet have a special team that carries out internal quality control programs, so it will be difficult to improve the quality status of schools based on the quality of quality achievement. Therefore it is necessary to start by designing school quality programs in accordance with the conditions and carrying capacity of school resources, there is no need to set targets and indicators that are too high and difficult to achieve, but the quality programs must be in accordance with school conditions, achieving quality in stages and stay focused to lead to meet education standards as well, then if you already have a better carrying capacity then continue to become a model school maybe even a reference school. However, the initial capital is the commitment of school residents to have a willingness to be better and quality through good cooperation in various quality program activities as stated by [9] that team work is the vital factor for schools in order to improve internal quality assurance operational effectiveness since team work supports performance, quality of working life, interaction, collaboration and it is the instrument in organizational development.

The programs in the school development plan are not clearly related to the quality program of the school quality assurance management. This is due to the fact that schools do not yet have a good and sustainable internal quality assurance system. So it is necessary to have a thorough joint assessment of the resources of the school to further improve the quality of schools through quality programs managed by the internal quality assurance system team. In addition there are a number of factors that affect internal quality assurance in the form of four factors of direct effect were administrators 'instructional leadership, innovation culture of organizations, opened climate of organization and teachers' leadership [9]. It also depends on the motivation of teachers is a quality assurance practice in secondary schools [6] and the quality assurance component aims to enhance teaching and learning as an integral feature of school improvement [10], including the emphasizing understanding and not memorization, the need for more group work and dialogue, restoring the visual-spatial aspects of learning, re-thinking curriculum balance, and reexamining national examination systems [11].

Preparation of programs related to quality improvement needs to pay attention to a number of factors that will affect as stated above related to teaching staff and education even including students who are the factors that determine the success of quality improvement, so with these considerations the failure rate will be minimized

In the context of the implementation of internal quality assurance, program determination and implementation as stated by [12] that the School through a predetermined mechanism can determine the stages of implementing quality management as follows: namely: plan (plan), do (implement), organizing, controlling and conducting evaluation stages (evaluating) on an ongoing basis. In addition, adequate facilities and equitable educators support will be required to have a significant impact on the implementation of the internal quality assurance system in schools [13]. Also to further improve quality assurance in relation to the learning process is shown by students expressed high satisfaction with the state of learning resources and the competence of the academic staff available to them [14] and must focus on economical , technical, and organizational dimensions as main dimensions of system feasibility [15].

Another thing to note is in the form of support from the government or the department in charge of education should continue to provide adequate infrastructure and facilities in the schools to create a conducive teaching and learning environment for both teachers and students [16], intensified and possible private participation in the practice should be complemented [17]. Also requires systems of quality control with regard to the actors, i.e. the stakeholders instead of the institutional configurations: (1) state control and accountability by bureaucratic means and legal regulations, (2) professional control and accountability, and (3) consumer control and accountability [18].

\section{CONCLUSIONS}

The level of understanding of school residents related to quality management and education is still at a low level which still needs to be improved before establishing a system of quality management of education units. In addition, the understanding of educators related to national education standards that are closely related to their work still needs to be improved so that there is still a need to increase understanding in order to be able to carry out the process and evaluation in accordance with the standards. It is necessary to develop the teaching and education staff in terms of knowledge and skills in the implementation of the quality of the education unit through a special team from external schools until the school is ready to be able to carry out internal quality management.

\section{REFERENCES}

[1] "Undang-undang No. 20 Tahun 2003 tentang sistem pendidikan nasional," Jakarta, 2003.

[2] J. W. Creswell, "Education research: Planning, conducting, and evaluating quantitative and qualitative research (3rd eds.)." Upper Saddle River: Pearson, 2008.

[3] Sugiyono, Memahami Penelitian Kualitatif. Bandung: Alfabeta, 2008

[4] Sugiyono, Metode Penelitian Pendidikan Pendekatan Kuantitatif, Kualitatif, dan RT \& D. Bandung: Alfabeta, 2008

[5] B. A. Lumosi and P. W. Mukonyi, "Quality Monitoring in Secondary Education in Kenya: A Comparative Analysis of Public Schools in Kakamega East and Kakamega Central Sub-Counties of Kakamega County," Int. J. Educ. Res., vol. 3, no. 1, 2015.

[6] N. Onuma and N. P. Okpalanze, “Assessment of Quality Assurance 
Practices inSecondary Schools in Enugu State Nigeria," Middle-East J. Sci. Res., vol. 25, no. 8, pp. 1695-1714, 2017.

[7] R. Nelson, M. Ehren, and D. Godfrey, Literature Review on Internal Evaluation. London: Institute of Education, 2015.

[8] S. O. Adegbesan, "Establishing quality assurance in Nigerian education system: Implication for educational managers," Educ. Res. Rev., vol. 6, no. 2, pp. 147-151, 2011.

[9] P. Praraksa, S. Sroinam, M. Inthusamith, and M. Pawarinyanon, “A model of factors influencing internal quality assurance operational effectiveness of the small sized primary schools in northeast thailand," Procedia-Social Behav. Sci., vol. 197, pp. 1586-1590, 2015 .

[10] C. Caesar, "Framework for Delivery of Quality Education: Examination of quality concepts to inform a framework for improving education quality in St Lucia a member of the Organization of Eastern Caribbean states (OECS)," Am. Acad. Sch. Res. J., vol. 5, no. 1, p. 17, 2013.

[11] K. Almadani, N. Reid, and S. Rodrigues, "Quality assurance: a pressing problem for education in the 21 st century," Probl. Educ. 21st Century, vol. 32, p. 9, 2011.

[12] S. Uchtiawati and I. Zawawi, "Penerapan Penjaminan Mutu Pendidikan pada Sekolah Menengah Atas berstandar Internasional," J. Kebijak. dan Pengemb. Pendidik., vol. 2, no. 1, 2014.
[13] Darman, Darwin, and Yusnadi, "Implication of Internal Quality Assurance System of Schools Implementation Against the Accreditation rating of State Senior High Schools of Natuna, Riau Island Province," J. Res. Method Educ., vol. 7, no. 5, pp. 36-39, 2017.

[14] H. B. Essel, M. Boakye-Yiadom, and F. A. Kyeremeh, "Assessing students' experiences of internal quality assurance practices in selected private higher education institutions," Int. J. Sci. Res., vol. 7, no. 2, pp. 804-809, 2018.

[15] F. Amir, "Developing Structure for Management of Quality in Schools: Steps towards Quality Assurance Systems," Am. J. Educ. Res., vol. 3, no. 8, pp. 977-981, 2015.

[16] B. K. Oyewole, "Repositioning secondary school administration for quality assurance in Ekiti State, Nigeria," J. Mgmt. Sustain., vol. 3, p. $173,2013$.

[17] I. Olufunke and S. Joseph, "Quality assurance and effectiveness of Lagos State junior secondary schools," Int. J. Humanit. Soc. Sci., vol. 2, no. 15, pp. 166-170, 2012.

[18] S. G. Huber and B. Gördel, "Quality assurance in the German school system,” Eur. Educ. Res. J., vol. 5, no. 3-4, pp. 196-209, 2006. 